\title{
PENERAPAN MODEL PEMBELAJARAN INKUIRI TERBIMBING UNTUK MENINGKATKAN HASIL BELAJAR PEMBELAJARAN IPS PADA SISWA KELAS IV SD TAMBAKPLOSO TURI LAMONGAN
}

\author{
Kiky Chandra Silvia Anggraini \\ Universitas Islam Lamongan \\ email: qcandra.sa@unisla.ac.id
}

\begin{abstract}
One of the problems at school and society is the low results of social studies learning. During this time social science is identical with boring learning so students are not interested in learning. The use of lectures used by the majority of teachers will be replaced by the application of the guided inquiry learning model. This type of research is a pre-experiment that involved class IV at SDN Tambakploso. Use of written tests as instruments for data collection. Sampling in this study was carried out with saturation. The research data were analyzed through SPSS version 25.00. Based on the results of the pretest and posttest in the experimental class that uses guided inquiry is more effective than the control class that performs pure inquiry to increase students' social sensitivity. Analysis with the t test found a significance value of 0,000 or smaller than 0.05 which indicates an alternative hypothesis was accepted
\end{abstract}

Keyword: Guided Inquiry, Learning Outcomes, IPS

\section{A. Pendahuluan}

Menurut UU No. 20 tahun 2003, pendidikan adalah usaha sadar dan terencana untuk mewujudkan suasana belajar dan proses pembelajaran agar peserta didik secara aktif mengembangkan potensi dirinya untuk memiliki kekuatan spiritual keagamaaan, pengendalian diri, kepribadian, kecerdasan, akhlak mulia, serta keterampilan yang diperlukan dirinya, masyarakat, bangsa, dan negara. Pendidikan harus mampu menuntun segala kekuatan kodrat yang ada pada anak, supaya anak menjadi manusia dan anggota masyarakat, yang memperoleh keselamatan dan kebahagiaan setinggi-tingginya.

Pendidikan berfungsi sebagai media penamanan sikap dan budi pekerti yang sarat dengan nilai kemanusian kini hanya slogan.Tanpa budi pekerrti akan mengakibatkan munculnya permasalahan sosial yang diakibatkan dari kurangnya kepekaan masyarakat sekitar. Tujuan dari pendidikan sebagai memanusiakan manusia tampaknya hanya pada ranah fisik belum sampai kepada tingkat jiwa sehingga pendidikan yang ada belum mampu mengubah perilaku dan karakter bangsa yang berperan sebagai mahluk hidup dan mahluk sosial. 
Permasalahan sosial tidak mungkin mampu ditangani hanya dengan salah satu disiplin ilmu saja tetap harus membutuhkan gabungan beberapa ilmu sosial untuk memecahkan atau mengatasi masalah sosial yang ada karena masalah sosial tersebut berkaitan dengan beberapa sebab yang melatarbelakangi sedangkan untuk mengatasi masalah harus tahu penyebab, oleh karena itu diperlukan kurikulum secara terintergrasi peserta didik memudahkan untuk mengidentifikasi masalah yang ada sekaligus mencari solusi, pada dasarnya permasalahan sosial tidak ada yang tunggal namun menjadi menjadi kesatuan.Pemerintah telah melakukan perbaikan dan perubahan kurikulum yang ada di Indonesia sebagai upaya penegasan fungsi dan tujuan pendidikan. Pemerintah kemudian merevisi pendidikan nasional yang sebelumnya KTSP menjadi kurikulum 2013.

Karakteristik kurikulum 2013 bukan lagi menuntut pemahaman pengetahuan saja, melainkan mengedepankan pada pengembangan keterampilan sosial dalam kegiatan pembelajaran sehingga diharapkan peserta didik mampu mengembangkan potensi yang ada dalam dirinya yang menunjang selama proses pembelajaran bahkan pembentukan kompetensi dalam situasi bermasyarakat

Munculnya mata pelajaran IPS pada tingkat SD dikarenakan pentingnya siswa dalam memberikan pengetahuan sadar akan kondisi sosial disekitar siswa. Istilah pendidikan IPS diambil dari social studies diharapkan dengan adanya kurikulum yang baru peserta didik paham dan sadar akan permalasahan sosial di sekitarnya (nasution, 2011).

National Comite for Social Studies (NCSS) memberikan definisi pengertian IPS yang secara eksplinsit maupun implisit telah banyak disepakati oleh para ahli IPS di Indonesia. Pengertian IPS menurut Nasitional Comite For Social Studies (NCSS) (Nasution, 2011) sebagai berikut. "Social studies is the integrated study of the science and humanities to promote civic competence. Whitin the school program, socisl studies provides coordinated, systematic study drawing upon such disciplines as anthropology, economics, geography, history, law, philosophy, political science, psychology, religion, and sociology, as well as appropriate content from the humanities, mathematics, and natural sciences. "“'Studi yang terintegrasi dari ilmuilmu sosial dan humaniora dalam rangka mengembangkan kompetensi warga negara. Didalam program sekolah, IPS mengkordinasikan, kajian sistematis yang menggambarkan berbagai ilmu disiplin seperti Antropologi, Arkeologi, Ekonomi, Sejarah, Hukum, Filsafat, Ilmu Politik, Psikologi, Agama, dan Sosiologi, maupun materi yang sesuai dari Humaniora, Matematika, dan Ilmu Alam".

Rumusan dari NCSS menunjukkan bahwa materi IPS semakin meluas karena gabungan dari berbagai disiplin ilmu, bukan hanya ilmu-ilmu sosial melainkan juga humaniora, matematika, ilmu alam bahkan agama. Pengintergrasian dikarenakan 
tujuan dari pendidikan IPS untuk membantu para remaja dalam mengembangkan potensinya agar menjadi warga negara yang baik (masyarakat demokrasi dan dapat berhubungan dengan bangsa-bangsa lain di dunia), maka pendidikan IPS disajikan sebagai mata pelajaran untuk siswa persekolahan dari TK sampai tingkat SLTA (Nasution, 2011))

Pada dasarnya tujuan pendidikan IPS adalah membantu siswa atau generasi muda agar menjadi warga negara yang baik dengan cara menjadi warga negera yang domokratis, mampu mengambil keputusan dalam membuat kebijakan umum, mengetahui dan mampu memberikan solusi atas permasalahan sosial yang tengah terjadi sekarang dan dimasa depan.

Menurut NCSS (1994) tujuan pendidikan IPS adalah membantu anak- anak muda dalam mengembangkan kemampuan untuk tanggap terhadap segala permasalahan kewarganegaraan dan dapat membuat keputusan-keputusan yang beralasan demi kebaikan umum, sebagai warga yang secara cultural berbeda, di dalam masyarakat demokratis dunia yang saling ketergantungan

Salah satu tujuan dari pendidikan IPS agar peserta didik mempunyai kepekaan dalam menganalis berbagai masalah dalam masyarakat dalam berbagai dimensi ilmu sosial. Apalagi bangsa Indonesia dikenal sebagai bangsa yang terdiri dari suku-suku bangsa yang dapat dengan mudah timbul pertentangan politik bangsa bahkan konflik antar suku, maka pendidikan IPS memiliki peranan bagi peserta didik untuk dapat mengembangkan kompetensi warga negara. Kompetensi warga negara yang dimaksud adalah kemampuan peserta didik dalam mengerti kondisi masyarakat, demokrasi, serta mampu mengambil keputusan dalam menghadapi berbagai permasalahan yang terjadi dalam masyarakat dan . Keterampilan sosial dasar bagi peserta didik dalam menjawab berbagai tantangan dimasa depan.

Menurut Pratiwi (2003) pembelajaran IPS masih terkendala kurangnya kemampuan guru dalam dalam mengintergrasikan berbagai disiplin ilmu sosial serta kurangnya guru yang mempunyai latar belakang sebagai guru IPS terpadu. Senada dengan Wahyudi (2011) pembelajaran IPS dianggap sebagai pembelajaran yang menjemukan dan hasil pembelajaran hanya mencapai kompentensi rendah (lower order thingking).

Hasil belajar adalah efek yang ada tentang sebuah peneapan strategi pembelajaran. Bloom menyatakan jika hasil belajar siswa melipti ranah kognitif, afektif, dan psikomotor. Ranah kognitif megcangkup kemampuan intelektual yang berkaitan dengan proses mental atau kegiatan dari katagori rendah ke tinggi. Ranah afaektif berkaitan dnegan peraasaan dan emosi. dan ranah psikomotorik merumpakan kompetensi melakukan kegiatan yang berkaiatan dengan gerakan fisik. 
Hasil belajar merupakan kemampuan yang diperoleh siswa setelah melalui kegiatan belajar. Karena belajar itu sendiri memiliki definisi suatu proses dari seseorang yang berusaha untuk memperoleh suatu bentuk perubahan perilaku yang relatif konstan. Siswa dikatakan berhasil dalam belajar apabila telah mencapai tujuantujuan pembelajaran (susanto, 2008).

Sistem pendidikan nasional rumusan tujuan pendidikan menggunakan klasifkasi hasil belajar dari Benyamin Bloom yang secara garis besar dibagi menjadi tiga ranah yaitu:

a. Ranah kognitif berkaitan dengan hasil belajar intelektual

b. Ranah afektif berkaitan dengan sikap.

c. Ranah psikomotorik berkaitan dengan hasil belajar keterampilan dan kemampuan bertindak.

Dari ketiga objek penelian tersebut yang paling banyak dinilai oleh guru adalah ranah kognitif karena keterkaitan dengan kemampuan siswa dalam menguasai isi materi pengajaran.

Pelaksanaan pembelajaran ips di sekolah, secara umum masih mengandalkan startegi pembelajaran ekspositori. Pelaksanaan pembelajaran yang selama ini banyak dilakukan oleh guru adalah pembelajaran ekspositori yang menggunakan strategi pembelajaran ekspositori. Namun tidak semua prinsip penggunaan strategi pembelajaran yang menyatakan bahwa tidak semua strategi pembelajaran cocok digunakan untuk semua tujuan dan keadaan (Sanjaya, 2011). Oleh karena itu, guru diharapkan mampu memlilih strategi yang cocok dengan keadaan siswa dan mata pelajaran.

Apabila seorang pendidik terus-terusan untuk melakukan strategi pembelajaran ekspositori maka semakin menurunkan kualitas pendidikan. Menurut Setyosari (2013) pembelajaran yang didominasi strategi pembelajaran ekspositori, keadaannya yang memprihatinkan dalam penyelenggaraan pendidikan.

Guru sebagai ujung tombak dalam dunia pendidikan, dituntut untuk mampu berinovasi atau mencarai model pembelajaran yang dapat membangkitkan semangat dan membangun keaktifan siswa di dalam kelas. Guru harus meninggalkan pembelajaran tradisional yang kaku dan menempatkan guru sebagai pusat pembelajaran. Guru harus mempunyai kemampuan menciptakan suasana kelas yang kondusif, riang, senang tanpa harus meninggalkan proses belajar sehingga siswa akan belajar dengan keadaan senang

Menurut Roger dalam Sapriya, inkuiri merupakan proses untuk mengajukan pertanyaan dan mendorong semangat belajar para siswa pada jenjang pendidikan dasar dan menengah. Menurut Bayer dalam sapriya mengatakan inkuiri lebih dari sekedar bertanya, inkuiri merupakan proses mempertanyakan makna atau arti tertentu 
yang menuntut seseorang menampilkan kemampuan intelektual agar ide atau pemikirannya dapat dipahami. Inkuiri merupakan proses bagi siswa untuk memecahkan masalah atau untuk memproses informasi. Bayer dalam Sapriya, inkuiri merupakan salah satu cara untuk mengetahui, lebih lanjut apabila orang terkait dalam proses investigasi, berusaha memecahkan masalah secara berkelanjutan, makan orang-orang ini telah melakukan proses inkuiri.

Massialas \& Cox dalam Wena, mengemukakan bahwa pemilih an strategi pembelajaran inkuiri untuk memecahkan masalah dalam pembelajaran social karena;(1) Strategi ini khusus dirancang untuk meningkatkan kemampuan dan keterampilan siswa dalam memecahkan masalah-masalahsosial; (2) Beberapa hasil penelitian menunjukkan bahwa Strategi inkuiri terbukti efektif meningkatkan kemampuan dan keterampilan siswa dalam memecahka nmasalah-masalah sosial; (3) Strategi ini merupakan sinkronisasi antara teori mengajar dan teori belajar, yang memilki prosedur yang sistematis dan mudah diterapkan oleh pengajar (Wena, 2009).

Pembelajaran inkuiri dapat dibedakan menjadi, inkuiri terbimbing (guided inquiry), inkuiri bebas (free inquiry approach), inkuiri bebas yang dimodifikasikan (modified free inquiry approach) (Herdian, 2018).

Pembelajaran menggunakan metode inkuiri pertama kali dikembangkan oleh Richard Suchman yang menginginkan agar peserta didik bertanya mengapa suatu peristiwa terjadi, kemudian peserta didik melakukan kegiatan, mengumpulkan dan menganalisis data, sampai akhirnya peserta didik menemukan jawaban dari pertanyaan tersebut pembelajaran inkuiri merupakan rangkaian kegiatan pembelajaran yang menekankan pada proses berpikir kritis dan analitis untuk mencari dan menemukan jawaban dari suatu masalah yang dipertanyakan (Herdian, 2018).

Menurut Sapriya (2011), desain pembelajaran yaang sangat dianjurkan dalam kegiatan belajar mengajar IPS ialah model pembelajaran inkuiri (inquiry approach). Sapriya (2011) menyebutkan model dalam pendidikan IPS baik digunakan adalah inkuiri. Adanya pendekatan inkuiri ini, diharapkan peserta didik akan mampu mencapai high order thingking atau kemampuan berpikir tinggi dalam suatu proses pendidikan IPS yang aktif dan menyenangkan. Penelitian ini menggunakan inkuiri terbimbing yang artinya dalam proses pencarian pengetahuan, peserta didik tidak dibiarkan dilepas untuk mendapatkan berbagai pengetahuan. Guru akan membimbing peserta didik untuk mendapatkan pengetahuan yang diperlukan sehingga akan tercapai fokus permasalah dan pengetahuan yang diinginkan dalam proses pembelajaran

Inkuiri merupakan stretegi pembelajaran untuk menganalisis sub kelompok masyarakat yang berguna mengembangkan anggota masyarakat ideal, sehingga siswa akan membangun pengetahuan yang berguna bagi diri dan masyarakat. Adanya 
pendekatan inkuiri ini, diharapkan siswa akan mampu mencapai high order thingking atau kemampuan berpikir tinggi. Siswa tidak dibiarkan dilepas untuk mendapatkan berbagai pengetahuan. Guru akan membimbing siswa untuk mendapatkan pengetahuan

Melalui pendidikan IPS di sekolah, diharapkan akan meningktkan hasil belajar IPS sehingga permasalahan rendahnya hasil belajar IPS bisa diatasi. Rumusan masalah dalam penelitian ini adalah (1). Bagimana penerapan model pembelajaran inkuiri terbimbing dalam pembelajaran IPS SDN Tambak Ploso Lamongan (2). Bagimana pengaruh model pembelajaran inkuiri terbimbing dalam pembelajaran IPS dapat meningkatkan hasil belajar IPS siswa Tambak Ploso Lamongan

Berdasarkan kerangka berpikir ilmiah, hipotesis diajukan setelah merumuskan masalah, hal ini cukup berasalan karena hipotesis yang dibangun berdasarkan jawaban sementara peneliti Hipotesis dalam penelitian ini sebagai berikut.

Ho : Tidak ada pengaruh dari penerapan model pembelajaran inkuiri terbimbing dalam meningkatkan hasil belajar IPS PADA Siswa Kelas IV SD Tambakploso Turi Lamongan

Ha : Ada pengaruh dari penerapan model pembelajaran inkuiri terbimbing dalam meningkatkan hasil belajar IPS PADA Siswa Kelas IV SD Tambakploso Turi Lamongan

\section{B. Metode}

Penelitian ini merupakan penelitian eksperimen semu yang mempunyai rancangan penelitian pretest dan postest control desain. Pretest dilakukan untuk mengetahui keadaan awal subjek penelitian sebelum diberikan perlakuan, sehingga peniliti akan mengetahui kondisi awal subjek penelitian dan kondisi setelah diberikan perlakuan yang hasilnya dapat dibandingkan atau dilihat perubahannya.Post test dilakukan untuk mengetahui keadaan subjek penelitian setelah diperlakukannya perlakuan.

Variabel dalam penelitian ini ada dua macam yaitu variabel bebas yaitu model pembelajaran inkuiri, sedangkan variable bebas adalah Hasilbelajar siswa. Sampel penelitian ini adalah kelas 5 atas pertimbangan hasil obeservasi dan wawancara peneliti sebelum melakukan penlitian. Tehnik pengumpulan data dilakukan dengan cara tes tulis yang diberikan selama waktu penelitian

Intrumen Tes tulis IPS Sebelumnya telah dilakukan uji validasi muka dan validadi butir soal. berdasarkan hasil validasi muka di dapatkan skor sebesar 93,5 yang berati soal valid untuk dilakukan penelitian. Sedangkan dari hasil validasi butir. 
yang dilakukan di luar sample uji coba kemudian dianalisis denggan nilai Corrected Item-Total Correlation berbantuan spss 16. Diketahui dari 20 soal uraian terdapat 20 soal yang tergolong valid. Setelah ditemukan validitasnya, maka perlu dilakukan pengukuran reabilitas, dapat ketahui jika nilai Alpha Cronbach.s yang dihasilkan sebesar 0.804. Berdasarkan koefisiensi reabilitas yang diatas 0,80, maka dapat dikatakan jika tes tulis IPS mempunyai tingkat reabilitas yang tinggi.

Teknik analisis data menggunakan uji paired sampel T-Tes yang sebelumnya akan dilakukan uji prasyarat yaitu uji normalitas.

\section{Hasil dan Pembahasan}

1. Penerapan model pembelajaran inkuiri terbimbing dalam pembelajaran IPS SDN Tambak Ploso Lamongan

Penelitian ini dilakukan tiga kali tatap muka dan dilakukan uji pretest sebelum dilakukan trement dan postest dilakukan setelah tretment. Setiap pertemuan menggunakan model inkuiri terbimbing dnegan sintaks dibawah ini

Tabel 1 Langkah-Langkah Model Pembelajaran Inkuiri Terbimbing

\begin{tabular}{|c|c|c|c|}
\hline No & $\begin{array}{l}\text { Langkah } \\
\text { Pembela- } \\
\text { jaran }\end{array}$ & Fase & Kegiatan Guru dan Siswa \\
\hline 1 & $\begin{array}{l}\text { Kegiatan } \\
\text { Awal }\end{array}$ & Pendahuluan & $\begin{array}{l}\text { 1. Memberi salam. } \\
\text { 2. Memberikan kata- kata motivasi kepada siswa } \\
\text { 3. Mengabsen siswa. } \\
\text { 4. Apersepsi }\end{array}$ \\
\hline \multirow{3}{*}{2} & \multirow{3}{*}{$\begin{array}{l}\text { Kegiatan } \\
\text { Inti }\end{array}$} & $\begin{array}{l}\text { Identifikasi } \\
\text { dan } \\
\text { penetapan } \\
\text { ruang lingkup } \\
\text { masalah }\end{array}$ & $\begin{array}{l}\text { 1. Guru menyampaikan tujuan pembelajaran } \\
\text { 2. Guru kemudian membagi kelas menjadi } 5 \\
\text { kelompok untuk melakukan diskusi dan } \\
\text { melakukan pengamatan . } \\
\text { 3. Guru meminta siswa untuk memahami } \\
\text { permasalahan yang akan dibahas }\end{array}$ \\
\hline & & $\begin{array}{l}\text { Perumusan } \\
\text { hipotesis }\end{array}$ & $\begin{array}{l}\text { 1. Guru bersama sama dengan siswa } \\
\text { merumuskan pertanyaan tentang suatu } \\
\text { permasalahan yang mengharuskan siswa untuk } \\
\text { menganalisisnya. } \\
\text { 2. Siswa di bimbing untuk merumuskan hipotesis. }\end{array}$ \\
\hline & & Merancang & 1. Guru menugaskan siswa untuk mengumpulkan \\
\hline
\end{tabular}




\begin{tabular}{|c|c|c|c|}
\hline No & $\begin{array}{l}\text { Langkah } \\
\text { Pembela- } \\
\text { jaran }\end{array}$ & Fase & Kegiatan Guru dan Siswa \\
\hline & & percobaan & $\begin{array}{l}\text { data atau informasi dari berbagai sumber. } \\
\text { 2. Guru membimbing siswa untuk mengumpulkan } \\
\text { dan memilih data }\end{array}$ \\
\hline & & $\begin{array}{l}\text { Interpretasi } \\
\text { data }\end{array}$ & $\begin{array}{l}\text { 1. Siswa akan menalar semua data atau } \\
\text { informasi yang telah didapat menjadi data } \\
\text { yang diperlukan dan dianalisis sesuai dengan } \\
\text { hipotesis yang sebelumnya dibuat. } \\
\text { 2. Siswa memberikan penjelasan tentang data } \\
\text { yang dibuat. } \\
\text { 3. Siswa mempresentasikan hasil laporan yang } \\
\text { telah dibuat di depan kelas }\end{array}$ \\
\hline & & $\begin{array}{l}\text { Mengembang } \\
\text { kan } \\
\text { kesimpulan }\end{array}$ & $\begin{array}{l}\text { 1. Siswa membuat kesimpulan terhadap suatu } \\
\text { permasalahan. }\end{array}$ \\
\hline 3 & $\begin{array}{l}\text { Kegiatan } \\
\text { Penutup }\end{array}$ & Penutup & $\begin{array}{l}\text { 1. Guru membimbing siswa untuk membuat } \\
\text { kesimpulan dari hasil diskusi siswa. Guru } \\
\text { memberikan penghargaan kepada siswa dengan } \\
\text { presentasi terbaik. } \\
\text { 2. Menutup pelajaran dengan salam }\end{array}$ \\
\hline
\end{tabular}

Terdapat enam kali pertemuan pada penelitian ini dengan menerapkan model pembelajaran inkuiri terbimbing pada kelas IV MI SDN Tambak Ploso Lamongan pada mata IPS, dan setiap pertemuan mempunyai tingkat keberhasilan yang berbeda dalam penerapan model pembelajaran inkuiri terbimbing.

Pertemuan pertama penerapan model pembelajaran inkuiri terbimbing siswa masih terlihat belum terbiasa model pembelajaran inkuiri terbimbing dengan baik, sehingga pada penerapan model pembelajaran inkuiri terbimbing belum maksimal.

Pertemuan kedua siswa sudah mulai beradaptasi dengan keadaan pada penerapan model Pembelajaran inkuiri terbimbing dan mulai menerima teman diskusinya serta terdapat beberapa kelompok yang berani mempresentasikan hasil kerja kelompoknya.

Pertemuan ketiga, semua siswa aktif dalam pembelajaran. Disetiap tahapnya mereka lalui dengan senang dan tertib dan siswa sudah terbiasa melakuak model inkuiri terbimbing dengan sangat baik.

Selama pembelajaran, guru yang melakukan model pembelajaran inkuiri terbimbing guru melakukan skenario sebagai berikut: 1) guru menunjukkan masalah 
dan mengajukan pertanyaan kepada siswa untuk dipecahkan dan dijawab. 2) siswa dibimbing oleh guru untuk menemukan jawaban sementara atas masalah yang ada. 3) siswa mencari berbagai bukti untuk mendukung hipotesis yang telah dibuat dan guru ditugasi membimbing siswa untuk mendapatkan data dengan benar. 4) siswa menganalisis masalah dengan dukungan data yang ada dan guru memiliki tugas memberikan berbagai pertanyaan untuk menumbuhkan kemampuan menganalisis. 5) guru dan siswa menyimpulkan bersama apa yang telah dilakukan. Langkah-langkah dalam inkuiri terbimbing mendorong siswa untuk membangun pengetahuan mereka (Blackmore \& Fraser, 2007).

Kelompok yang mendapatkan perlakuan dengan menggunakan model inkuiri Kelas ini mendapatkan pengujian sebanyak 2 kali yaitu pretest dan posttest. Pretest dilakukan sebelum siswa mendapatkan model pembelajaran inkuiri murni, sedangkan posttest adalah pengujian yang dilakukan setelah model pembelajaran inkuri murni dilakukan. Adapun hasil dari nilai pretest ,hal ini nampak pada Tabel 1 sebagai berikut:

Tabel 1 Distrbusi Statistik hasil belajar siswa

\begin{tabular}{|lr|r|r|r|r}
\multicolumn{5}{c}{ Descriptive Statistics } & \\
& N & Minimum & Maximum & Mean & Std. Deviation \\
\hline Pretest & 25 & 40 & 65 & 54,40 & 7,118 \\
\hline Posttest & 25 & 75 & 100 & 86,60 & 7,176 \\
\hline Valid N (listwise) & 25 & & & & \\
\hline
\end{tabular}

Berdasarkan tabel 1 dapat diketahui pada siswa yang mendapatkan pretest nilai minimumnya adalah 40 sedangkan nilaimaksimmumnya sebesar 65. Setelah diberikan perlakuan akam diujikan kembali melalui kegiatan posttest siswa mendpaatkan nilai minimum sebesar 75 dan nilai maksimumnya sbeesar 100 . diketahui jika nilai maksimum siswa paling besar didapatkan saat uji posstest. Yang secara tidak langsung menyatakan jika model inkuiri terbimbing bisa meningkatkan hasil belajar siswa . hal ini nampak pada grafik 1 dibawah ini: 
Grafik 1. Grafik Uji Pretest dan Posstest Hasil Belajar Siswa

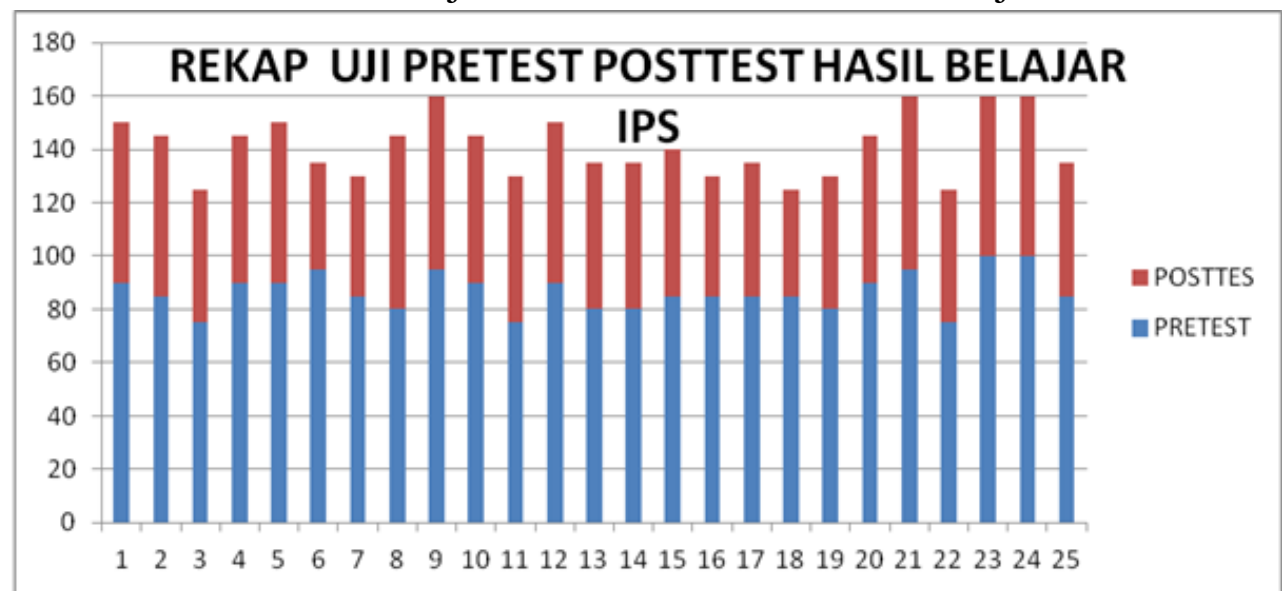

Sebelum peneliti melakukan uji hipotesis maka dilakukan uji yang akan mengukur prasayart dari uji SPSS Paired Sampel T-TES dengan melakukan uji normaloitas yang bertujuan untuk menguji kenormalan data dalam penelitian ini. Pengujia uji nornmalitas tampak pada tabel 2 berikut ini:

Tabel 2. Uji normalitas

One-Sample Kolmogorov-Smirnov Test

\begin{tabular}{|c|c|c|c|}
\hline & & Pretest & Posttest \\
\hline $\mathrm{N}$ & & 25 & 25 \\
\hline \multirow[t]{2}{*}{ Normal Parameters ${ }^{\mathrm{a}, \mathrm{b}}$} & Mean & 86,60 & 54,40 \\
\hline & $\begin{array}{l}\text { Std. } \\
\text { Deviation }\end{array}$ & 7,176 & 7,118 \\
\hline \multirow{3}{*}{$\begin{array}{l}\text { Most } \\
\text { Differences }\end{array}$} & Absolute & ,148 & , 174 \\
\hline & Positive & , 148 & , 106 \\
\hline & Negative &,- 132 &,- 174 \\
\hline \multicolumn{2}{|l|}{ Test Statistic } & ,148 & , 174 \\
\hline \multicolumn{2}{|l|}{ Asymp. Sig. (2-tailed) } &, $163^{c}$ &, $050^{\mathrm{c}}$ \\
\hline
\end{tabular}

a. Test distribution is Normal.

b. Calculated from data.

c. Lilliefors Significance Correction.

Berdasarkan Uji Normaltas diatas dikethui jika nilai uji normalitas data pretest dan Posttest lenih besar dari 0.05 . jadi berati nilainya pretest dan posttes berasal dari data yang berdistribusi normal. Tahapan pengujian selanjutnya adalah uji Paired 
Sampel T tes yang dilakukan dengan bantunan SPSS. berikut ini tabel 3 adalah hasil dari uji Paired Sampel T tes berikut.

\section{Tabel 3. Uji Paired T Tes}

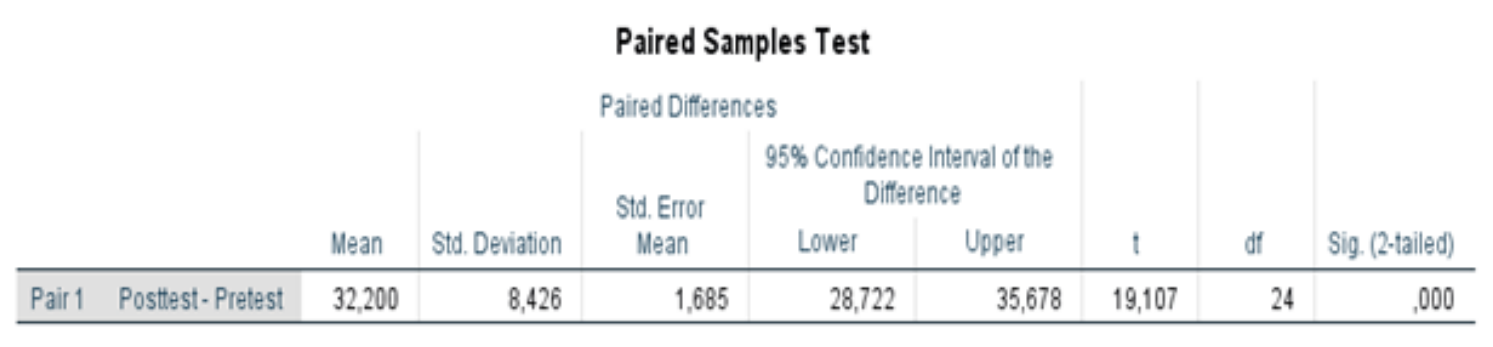

Berdasarkan uji paired sampel t tes diketahui jika nilai signifikansi sebensar 0,000 yang lebih besar dari sig 0,05 yang artinya terdapat pengaruh model inkuiri terbimbing untuk meningktkanhasil belajar siswa.

Selama pembelajaran, guru yang melakukan model pembelajaran inkuiri terbimbing guru melakukan skenario sebagai berikut: 1) guru menunjukkan masalah dan mengajukan pertanyaan kepada siswa untuk dipecahkan dan dijawab. 2) siswa dibimbing oleh guru untuk menemukan jawaban sementara atas masalah yang ada. 3) siswa mencari berbagai bukti untuk mendukung hipotesis yang telah dibuat dan guru ditugasi membimbing siswa untuk mendapatkan data dengan benar. 4) siswa menganalisis masalah dengan dukungan data yang ada dan guru memiliki tugas memberikan berbagai pertanyaan untuk menumbuhkan kemampuan menganalisis. 5) guru dan siswa menyimpulkan bersama apa yang telah dilakukan.

Penggunaan contoh kasus yang dekat dengan siswa baik dalam memberikan pengalaman langsung atau melalui media akan mudah diingat dan dianalisis oleh siswa. Misalnya, kasus kebakaran hutan, banjir, tanah longsor, perkotaan dan pedesaan. Ada contoh kasus yang diketahui siswa akan lebih mudah digeneralisasi selama proses pembelajaran dengan menambahkan teori yang relevan dengan bantuan guru. Contoh kasus dari pengalaman pribadi akan mudah digeneralisasi oleh siswa. Selama proses penyelidikan, siswa berlatih sambil mengembangkan keterampilan sosial mereka, tetapi guru juga terlibat dalam mengembangkan keterampilan sosial yang dimiliki siswa Berdasarkan langkah-langkah model pembelajaran inkuiri terbimbing

\section{Simpulan}

Setelah dilukan observai dan tes terhadap hasil besar, diketahui jika model inkuiri terbiing bisa meningktkan hasil belajar siswa. Hal ini dibuktikan dengan meningkatnya nilai postest dibandingkan dnegna nilai pretsest. Hal ini diperkuat dengan uj statsitik yang menunjuukan jika ada pengaruh model inkuiri terbikbing terhdap hasil belajar siswa. 


\section{Daftar Rujukan}

Herdian. (2018). Model Pembelajaran Inkuiri. dalamhttps://herdy07wordpress.com/2010/05/27/model/pembelajaran/inkuiri.ht $\underline{\mathrm{ml}}$.

Made Wena. (2009). Strategi Pembelajaran Inovatif Kontemporer. Jakarta: PT Bumi Aksara.

Nasution. (2011). Kajian Pembelajaran IPS di Sekolah. Surabaya: Unesa Press.

Sapriya. (2011). Pendidikan IPS Konsep dan Pembelajaran. Bandung: PT Remaja Rosdakarya.

Rizema Putra, Sitiatava. (2013) Desain Belajar Mengajar Kreatif Berbasis Sains, Yogyakarta: Diva Press.

Susanto, Ahmad. (2015). Teori Belajar \& Pembelajaran Di Sekolah Dasar. Bandung: PT Remaja Rosdakarya. 